\title{
Chemical Composition of Saline Sources as Suppliers of Minerals for Ruminants
}

\author{
Daniel Bomfim Manera ${ }^{1}$, Tadeu Vinhas Voltolini ${ }^{2}$, Daniel Ribeiro Menezes ${ }^{1} \&$ Gherman Garcia Leal de Araújo ${ }^{2}$ \\ ${ }^{1}$ Universidade Federal do Vale do São Francisco (Univasf), Petrolina/PE, Brazil \\ ${ }^{2}$ Embrapa Semiárido, Petrolina/PE, Brazil \\ Correspondence: Tadeu Vinhas Voltolini, Embrapa Semiárido, BR 428, Km 152, Zona rural, CEP 56302-210, \\ Petrolina/PE, Brazil. Tel: 87-3866-3657.E-mail: tadeu.voltolini@embrapa.br
}

\author{
Received: January 12, $2016 \quad$ Accepted: August 22, $2016 \quad$ Online Published: November 15, 2016 \\ doi:10.5539/jas.v8n12p138 URL: http://dx.doi.org/10.5539/jas.v8n12p138
}

\begin{abstract}
This study aimed to evaluate the mineral composition of solid residues (SR) from desalination waste (DWSR), saline water (SWSR) and aquaculture ponds (APSR), and to discuss the results based on ruminant requirements. Mineral determined were K, P, Ca, Mg, S, Cu, Fe, Mn, Zn, Na, Cl, Ni, Pb, Cd and Cr, from 24 samples, 4 DWSR, 10 SWSR and 10 APSR, with three replicates. Desalination waste solid residue, SWSR and APSR had large variation of minerals. Saline water solid residue and DWSR presented potential to be used as source of $\mathrm{Na}$ and $\mathrm{Cl}$, while the APSR can contribute Ca. All examined saline sources were poor in P, Ca and trace minerals except the APSR, showing a considerable concentration of Ca. Some samples of SWSR and APSR presented mineral concentrations that may be potentially toxic to ruminants.
\end{abstract}

Keywords: animal watering, desalination brine, water quality

\section{Introduction}

The literature emphasizes the need of minerals for grazing and feedlot ruminants such as cattle, goats and sheep and also their deficiency, which may promote nutritional (Herdt \& Hoff, 2011), reproductive (Mendonça Junior et al., 2011) and productive disorders (Tokarnia et al., 1999).

The Brazilian semi-arid presents mineral sources currently regarded as environmental pollutants, which may be evaluated as sources to mineral mix, as is the case of solid residues from desalination waste, aquaculture ponds and saline water (Manera et al., 2014).

The dumping of desalination waste directly in the soil may promote environmental implications (Amorim et al., 2004a; Xu et al., 2013), it is important, then, to search for alternative methods to waste disposal. On the other hand, these saline sources may provide ingredients and raw materials for animal supplementation and contribute to their destination.

According to $\mathrm{Xu}$ et al. (2013), the desalination waste shows potential to be used for different purposes. In addition, evaporation and crystallization are strategies to reduce the amount of effluents to obtain solid residues (Amorim et al., 2000; Porto et al., 2001). Kim (2011) also points out effluent evaporation as one of the cheapest method to recuperate salts.

However, little is known about the characteristics of solid residues from desalination waste, saline water and aquaculture ponds, especially on their physic-chemical compositions. This information may be useful to understand their potential as minerals sources for ruminants.

Thus, this study aimed to evaluate the mineral composition of solid residues from desalination waste, saline water and aquaculture ponds and discuss the results based on ruminant requirements.

\section{Material and Methods}

This study lasted from March 2011 to March 2012. We collected ten samples of solid residues from aquaculture ponds, ten from saline water and four samples of desalination waste, totaling 24 samples, with three replicates. Desalination waste and solid residues from aquaculture ponds were collected in Petrolina-PE, Tauá-CE and Santa Brigida-BA, Brazil. Saline water samples were collected in the municipalities of Jaguarari, Santa Brígida and Pintadas, in Bahia State; Lagoa Grande and Petrolina, in Pernambuco State; and Tauá, in Ceará State, Brazil. 
Water samples and desalination waste were stored in labeled plastic bottles, sent to the Laboratory of Animal Nutrition and kept in a freezer until the moment for chemical analyses.

Approximately $25 \mathrm{~L}$ of saline water and desalination waste were distributed in plastic trays and placed in a forced air-circulation oven at $55^{\circ} \mathrm{C}$ until the water evaporated. The accumulated solid residue was collected, sampled, stored in collection-type plastic jars and analyzed for the chemical properties. Solid residues from saline and desalination waste were named SWSR and DWSR, respectively.

The solid residue from aquaculture ponds (APSR) were collected directly from the ponds, after fish harvesting operations. Samples were stored and dried in a forced air-circulation oven at $55{ }^{\circ} \mathrm{C}$ until they generated the dry residue.

All samples had their mineral compositions determined at the Soil Laboratory of Embrapa Semiárido. The concentrations of potassium $(\mathrm{K})$, phosphorus $(\mathrm{P})$, calcium $(\mathrm{Ca})$, magnesium $(\mathrm{Mg})$, sulfur $(\mathrm{S})$, copper $(\mathrm{Cu})$, iron $(\mathrm{Fe})$, manganese $(\mathrm{Mn})$, zinc $(\mathrm{Zn})$, sodium $(\mathrm{Na})$, chlorine $(\mathrm{Cl})$, nickel $(\mathrm{Ni})$, lead $(\mathrm{Pb})$, cadmium $(\mathrm{Cd})$ and chromium (Cr) were determined according to the methodologies described by Nogueira et al. (2005).

The determination of mineral levels in APSR, SWSR and DWSR followed the same methodology. For this purpose, $10 \mathrm{~g}$ of sample were solubilized in $150 \mathrm{~mL}$ deionized water. Mineral levels were determined as $\mathrm{g}$ or $\mathrm{mg} / \mathrm{L}$ and then converted to $\mathrm{g}$ or $\mathrm{mg} / \mathrm{kg}$ for SWSR and DWSR.

Sodium and potassium were determined by photometry, whereas $\mathrm{Ca}$ and $\mathrm{Mg}$ were analyzed by titration, determining the $\mathrm{Ca}$ contents and subsequently the $\mathrm{Ca}+\mathrm{Mg}$, defining the $\mathrm{Mg}$ concentration as the difference. Chlorine and sulfur were determined indirectly, by first obtaining the chlorine and sulfate concentrations and considering their molecular weight, the $\mathrm{S}$ and $\mathrm{Cl}$ concentrations were determined.

Phosphorus was determined using molecular spectrophotometer and the determination of $\mathrm{Cu}, \mathrm{Fe}, \mathrm{Mn}, \mathrm{Zn}, \mathrm{Ni}, \mathrm{Pb}$, $\mathrm{Cd}$ and $\mathrm{Cr}$ was performed on an atomic absorption spectrophotometer (model Analyst 100, Perkin Elmer ${ }^{\circledR}$ ). The data were presented as descriptive statistics (means and standard deviations).

\section{Results and Discussion}

On average, Na levels in the DWSR and SWSR were $508.08 \mathrm{~g} / \mathrm{kg}$ and $412.09 \mathrm{~g} / \mathrm{kg}$, respectively. A smaller average was observed for APSR (5.11 g/kg). The $\mathrm{Cl}$ showed the greatest concentration (over $400 \mathrm{~g} / \mathrm{kg}$ ) in the DWSR and SWSR and low levels in the APSR (Table 1). The concentrations of P, K, Ca, Mg and S in the three types of solid residue were low (Table 1). The highest P and K levels were $5.64 \mathrm{~g} / \mathrm{kg}$ and $19.61 \mathrm{~g} / \mathrm{kg}$, respectively, equivalent to $0.056 \%$ and $1.99 \%$, both in the APSR.

The highest average of $\mathrm{P}$ was found in the APSR $(3.07 \mathrm{~g} / \mathrm{kg})$, possibly due to the fish ration supply, increasing this mineral in the solid residue. However, in general, the $\mathrm{P}$ levels were low, adding a small contribution potential to the animal. The bicalcium phosphate, a traditional $\mathrm{P}$ source with $18 \%$ of this mineral has a high bioavailability.

In Brazil, phosphorus concentration in the soil and pasture is low (Peixoto et al., 2005), therefore this mineral occupies an elevated proportion in the mineral mix for ruminants (Malafaia et al., 2014). Phosphorus can cause environmental contamination (Castillo et al., 2013), which can be supplemented to the animal in different ways (water, food) (Karn, 2001) and its deficiency can cause ossuary disorders and weakness (Prasad et al., 2015).

Powder supplements are mostly used in Brazil for mineral supplementation of domestic ruminants and are considered a low cost method. The dehydration of desalination waste by evaporation or crystallization tanks may constitute a potential method to include the residues in the animal diets and as destination of possible contaminants.

Amorim et al. (2000) used crystallization tanks and observed $36.06 \mathrm{~kg}$ of salts from $5.000 \mathrm{~L}$ of brine from desalting, equivalent to $7.21 \mathrm{~g} / \mathrm{L}$. Out of the total solid residues obtained, $79.03 \%$ corresponded to $\mathrm{NaCl}, 8.67 \% \mathrm{of} \mathrm{MgCl}_{2}$, $4.99 \%$ of $\mathrm{CaSO}_{4}, 4.72 \%$ of $\mathrm{MgSO}_{4}$ and $2.45 \%$ of $\mathrm{CaCl}_{2}$, having potential for industrial use and/or for animal feeding. Xu et al. (2013) reported that several chemical compounds could be obtained from the desalination waste for different purposes.

Evaporation is a potential strategy aimed to disposal the desalination waste (Porto et al., 2001) and the evaporation tanks have been adopted in some countries, especially in localities with high insolation and availability of lands at low cost. However, this strategy may lead to an increase in the concentration of minerals such as selenium, boron and heavy metals, reaching potentially toxic levels (Soares et al., 2006). Amorim et al. (2004b) also pointed out the use of solar evaporation as a tool to improve the handling of residues. The procedure of crystallized salts is the result of water evaporation by salts precipitation. Economically valuable products from these residues may be important to the desalination process which can be influenced by the procedure method, generally selective to a 
particular product, increasing production costs (Shahmansouri et al., 2015). In the current study the procedure method was non-selective and contained a set of mineral elements, which may have an important advantage.

In the current study, high presence of $\mathrm{Na}$ and $\mathrm{Cl}$ in the SWSR and DWSR suggest that $\mathrm{NaCl}$ is the main salt in these sources. When it comes to the level of $\mathrm{Ca}$, the content in the DWSR was, on average, $37 \mathrm{~g} / \mathrm{kg}$, however, one of the samples showed $89 \mathrm{~g} / \mathrm{kg}$. The concentration observed in the monocalcium phosphate used in the elaboration of mineral mix is $159 \mathrm{~g} / \mathrm{kg}$, higher than presented in the DWSR. One SWSR showed $16.02 \%$ of Ca and one APSR had $12.00 \%$, which are close to the levels of monocalcium and bicalcium phosphate. However, it should be noted that the mono and bicalcium phosphates present high bioavailability of $\mathrm{Ca}$.

Table 1. Macro minerals concentrations $(\mathrm{g} / \mathrm{kg})$ in salts samples obtained from saline water (SWSR), aquaculture ponds (APSR) and desalination waste (DWSR)

\begin{tabular}{|c|c|c|c|c|c|c|c|}
\hline Sample & $\mathrm{P}$ & $\mathrm{K}$ & $\mathrm{Ca}$ & $\mathrm{Mg}$ & $S$ & $\mathrm{Na}$ & $\mathrm{Cl}$ \\
\hline \multicolumn{8}{|l|}{$S W S R$} \\
\hline 1 & 1.27 & 4.68 & 124.20 & 79.39 & 13.88 & 322.00 & 405.90 \\
\hline 2 & 0.98 & 3.67 & 76.00 & 69.11 & 20.47 & 276.00 & 407.68 \\
\hline 3 & 2.66 & 2.26 & 80.00 & 57.03 & 20.02 & 460.00 & 400.59 \\
\hline 4 & 3.63 & 2.11 & 76.20 & 46.85 & 20.21 & 460.00 & 393.50 \\
\hline 5 & 1.70 & 1.01 & 108.36 & 79.17 & 15.62 & 391.00 & 451.99 \\
\hline 6 & 1.41 & 4.68 & 60.12 & 41.33 & 18.53 & 506.00 & 421.50 \\
\hline 7 & 1.27 & 1.17 & 104.76 & 80.85 & 15.27 & 368.00 & 356.27 \\
\hline 8 & 1.63 & 4.99 & 80.00 & 65.80 & 19.45 & 414.00 & 434.26 \\
\hline 9 & 2.56 & 4.84 & 160.24 & 60.17 & 14.98 & 230.00 & 384.63 \\
\hline 10 & 1.27 & 5.85 & 53.47 & 58.25 & 28.75 & 483.05 & 467.99 \\
\hline 11 & 2.35 & 2.46 & 28.92 & 31.09 & 31.51 & 414.04 & 292.49 \\
\hline 12 & 1.27 & 0.78 & 1.68 & 44.78 & 20.28 & 621.00 & 412.99 \\
\hline Mean & 1.83 & 3.21 & 79.50 & 59.49 & 19.91 & 412.09 & 402.48 \\
\hline SD & 0.76 & 1.71 & 40.50 & 15.52 & 5.13 & 101.77 & 43.68 \\
\hline \multicolumn{8}{|l|}{$A P S R$} \\
\hline 1 & 2.89 & 0.29 & 29.50 & 1.63 & 4.50 & 0.94 & 0.02 \\
\hline 2 & 5.64 & 19.61 & 29.25 & 1.50 & 3.35 & 1.60 & 0.03 \\
\hline 3 & 3.92 & 3.70 & 52.50 & 2.95 & 3.33 & 1.66 & 0.05 \\
\hline 4 & 4.57 & 3.09 & 63.50 & 3.15 & 5.58 & 14.46 & 0.03 \\
\hline 5 & 0.94 & 0.57 & 106.00 & 2.35 & 7.50 & 3.96 & 0.00 \\
\hline 6 & 3.79 & 0.57 & 101.00 & 2.00 & 8.83 & 4.81 & 0.01 \\
\hline 7 & 1.93 & 0.57 & 95.35 & 1.65 & 5.38 & 6.01 & 0.01 \\
\hline 8 & 2.76 & 0.57 & 99.00 & 1.30 & 5.42 & 4.67 & 0.01 \\
\hline 9 & 2.87 & 1.58 & 98.50 & 3.35 & 7.97 & 9.39 & 0.01 \\
\hline 10 & 1.37 & 0.57 & 120.00 & 2.70 & 8.00 & 3.65 & 0.00 \\
\hline Mean & 3.07 & 3.11 & 79.46 & 2.26 & 5.98 & 5.11 & 0.02 \\
\hline $\mathrm{SD}$ & 1.45 & 5.92 & 33.01 & 0.75 & 1.98 & 4.11 & 0.02 \\
\hline \multicolumn{8}{|l|}{$D W S R$} \\
\hline 1 & 3.46 & 0.94 & 15.50 & 20.11 & 19.02 & 690.00 & 298.67 \\
\hline 2 & 2.45 & 3.20 & 21.78 & 27.68 & 19.48 & 563.50 & 458.19 \\
\hline 3 & 1.27 & 5.15 & 89.20 & 69.18 & 18.53 & 368.00 & 450.22 \\
\hline 4 & 3.28 & 4.21 & 21.48 & 165.51 & 22.71 & 414.00 & 485.67 \\
\hline Mean & 2.62 & 3.37 & 36.99 & 70.62 & 19.94 & 508.88 & 423.18 \\
\hline SD & 1.00 & 1.81 & 34.93 & 66.84 & 1.89 & 146.78 & 84.39 \\
\hline
\end{tabular}

Note: $\mathrm{Ca}=$ calcium; $\mathrm{Mg}=$ magnesium; $\mathrm{Na}=$ sodium; $\mathrm{K}=$ potassium; $\mathrm{S}=$ sulfur $\mathrm{Cl}=$ chlorine; $\mathrm{P}=$ phosphorus; $\mathrm{SD}=$ standard deviation . 
The differences in composition among samples of APSR for Ca, ranging from 29.25 to $120.00 \mathrm{~g} / \mathrm{kg}$, is probably due to the composition of the desalination waste that filled the pond, but may also be justified by the amount of feed supplied or by the concentration of nutrients in the ration. Calcium is the main structural component of bones and teeth and its deficiency can cause rickets, osteomalacia and milk fever (NRC, 2001). However, an excess of Ca can cause hypercalcemia or calcification of body tissues (McDowell, 1989), where $1.50 \%$ of DM is pointed as the maximum level in the diet (NRC, 2005).

The Ca:P ratio was high, on average 43.44:1, 25.88:1 and 14.12:1 for SWSR, APSR and DWSR, respectively. The same Ca:P ratio was found for the vast majority of analyzed samples, which may lead to a nutritional imbalance and affect mineral absorption. The 2:1 Ca:P ratio is recommended at the NRC (2007). In Brazilian legislation on mineral mix for bovines, Ca:P ratio of 1:1 of up to 7:1 can be accepted (MAPA, 2004).

The average concentrations of Mg were low, being 5.95\%, $0.023 \%$ and $7.06 \%$ for SWSR, APSR and DWSR, respectively. Traditional $\mathrm{Mg}$ sources as magnesium sulfate present $20 \%$ of this mineral and magnesium carbonate and magnesium oxide present $31 \%$ and $55 \%$ of $\mathrm{Mg}$, respectively. One DWSR showed $16.55 \%$ of $\mathrm{Mg}$, which is expressive because it approximates to the levels found in magnesium sulfate. A high level of $\mathrm{Mg}$ in the diet may restrict feed intake and cause diarrhea, which may also affect the absorption of other elements such as P (NRC, 2001). Levels of $\mathrm{Mg}$ above $0.60 \%$ of $\mathrm{DM}$ are considered as the maximum tolerable, promoting intoxication, urothiliasis and reducing the productive performance (NRC, 2007). Amorim et al. (2004b) reported predominant occurrence of sodium but also magnesium in the desalination salts.

The mineral variation found in all solid residues showed heterogeneous composition, even those in the same group (SWSR, DWSR and APSR), which can be attributed to a series of factors, such as its origin and the water desalination procedures.

Potassium and S levels were low in the examined residues, especially for K. Desalination waste solid residue, SWSR and APSR showed similar average compared to K (3.11 to $3.37 \mathrm{~g} / \mathrm{kg})$, which was also observed in the SWSR and DWSR for S, presenting 19.91 and $19.94 \mathrm{~g} / \mathrm{kg}$, respectively, while the APSR showed $5.98 \mathrm{~g} / \mathrm{kg}$. Potassium deficiency can cause a reduction in growth, productive performance and feed intake (PULS, 1994). Potassium is an element to be considered in the prenatal stage, when supplementation of anionic diets can be a strategy to reduce the incidence of metabolic and nutritional disorders (Wilkens et al., 2012).

Both $\mathrm{Na}$ and $\mathrm{Cl}$ showed low levels in the APSR, and this can be attributed to the hydric circulation of the ponds. The APSR receives the brine from desalting and it shows a daily renewal to maintain a favorable aquatic environment. In this way, the brine that leaves the tank may contain a high salt concentration, especially $\mathrm{Na}$ and $\mathrm{Cl}$.

The concentrations of $\mathrm{Na}$ and $\mathrm{Cl}$ in the SWSR and DWSR may constitute these residues as alternatives sources of $\mathrm{Na}$ and $\mathrm{Cl}$. Desalination waste solid residue had, on average, $79.5 \mathrm{~g} / \mathrm{kg} \mathrm{Ca}$, which may reduce the inclusion of traditional $\mathrm{NaCl}$ source by $15 \%$ in the mineral mix for sheep. Although they were found at low amount, $\mathrm{Mg}, \mathrm{K}, \mathrm{S}$ and $\mathrm{P}$ averaged 59.49, 3.21, 19.91 and $1.83 \mathrm{~g} / \mathrm{kg}$, respectively, and should not be discounted as mineral suppliers.

The replacing of $\mathrm{NaCl}$ by SWSR may represent a reduction in the production costs, since the SWSR can be obtained at lower costs, but the main purpose of the inclusion of solid residues as SWSR and DWSR is the reduction in the environmental damage. The mineral profile of DWSR reflected the chemical composition of the waste itself, showing higher prevalence of $\mathrm{Na}$ and $\mathrm{Cl}$.

Sodium deficiency is one of the most important deficiencies among ruminants throughout the world since there is a shortage of $\mathrm{Na}$ in pastures in all continents. However, chlorine deficiency in ruminants is much more difficult to occur (Tokarnia et al., 2000). Sodium chloride is seen as a universally safe and cheap supplement for ruminants with important functions such as the acid-base balance, water metabolism and control of osmotic pressure. Sodium chloride can be considered attractive for the mineral mix intake by the animal, but also exerts a limitation on intake when given in excess. An adult bovine ingests about 30 to $35 \mathrm{~g}$ of $\mathrm{NaCl}$ daily (Tokarnia et al., 2000; Peixoto et al., 2005).

The two main sources of $\mathrm{Na}$ as mineral supplements for ruminants are sodium chloride and sodium bicarbonate, with $400 \mathrm{~g} / \mathrm{kg}$ and $270 \mathrm{~g} / \mathrm{kg}$ of sodium, respectively. The SWSR, DWSR and APSR showed $412.09 \mathrm{~g} / \mathrm{kg}, 508.88$ $\mathrm{g} / \mathrm{kg}$ and $51.10 \mathrm{~g} / \mathrm{kg}$, on average, respectively. High Na levels for the SWSR and DWSR are indicative of these solid residues as potential sources for mineral supplements.

According to NRC (2005) it is described that toxicity to $\mathrm{NaCl}$ is observed from the intake of over $4.0 \%$ of DM, or $25.20 \mathrm{~g} /$ day for animal with intake of $630 \mathrm{~g} /$ day of DM. In addition, the low levels of $\mathrm{P}, \mathrm{K}, \mathrm{Ca}$ and $\mathrm{Mg}$ in relation to the traditional mineral sources suggest low intoxication potential. 
The smallest macro minerals concentrations in the APSR in comparison to SWSR and DWSR suggest high level of organic matter and nitrogen in the APSR, possibly due to the fish feed or because of presence of impurities. Amorim et al. (2004b) reported that the presence of impurities is one of the factors compromising its use.

The $\mathrm{Cu}, \mathrm{Mn}, \mathrm{Zn}$ and Ni levels were low in the three examined residues (Table 2). The APSR showed the highest average of these four elements and of the total trace minerals. Furthermore, a heterogeneous concentration of trace mineral was observed in the three types of residues, which $\mathrm{Mn}$, for example, was $1.83 \mathrm{mg} / \mathrm{kg}, 34.78 \mathrm{mg} / \mathrm{kg} \mathrm{and}$ $192.90 \mathrm{mg} / \mathrm{kg}$, respectively in SWSR, DWSR and APSR. Just as the heterogeneity in mineral concentration, in the same type of residue, $\mathrm{Zn}$ showed a concentration of $0.30 \mathrm{mg} / \mathrm{kg}$ to $8.50 \mathrm{mg} / \mathrm{kg}$ in SWSR and 71.25 to $325 \mathrm{mg} / \mathrm{kg}$ in DWSR.

The highest average of $\mathrm{Cu}$ was found in the APSR with $16.9 \mathrm{mg} / \mathrm{kg}$. The other two groups of residues presented values below $0.40 \mathrm{mg} / \mathrm{kg}$. Copper sources to mineral mix for ruminants, such as copper sulfate shows $25 \%$ of this mineral, while copper oxide may reach up to $75 \%$ of $\mathrm{Cu}$. Copper plays an important role for the enzymatic systems and its deficiency is associated with anemia (NRC, 2005). Mohammed et al. (2014) reported that $\mathrm{Cu}$ is one of the limiting minerals for ruminants in pastures in Asia, Africa and Latin America and its deficiency may promote reduction in growth, ossuary disorders, diarrhea and infertility.

Manera (2013) studied the $\mathrm{Cu}$ concentration in commercial mineral mix for lambs in Brazil and reported average of $463 \mathrm{mg} / \mathrm{kg}$, ranging from 200 to $800 \mathrm{mg} / \mathrm{kg}$. Considering the amount of $10 \mathrm{~g} /$ day of the mineral mix in daily intake containing $463 \mathrm{mg} / \mathrm{kg}$ of $\mathrm{Cu}$, ingestion would be $4.63 \mathrm{mg} /$ day. The maximum tolerable level of $\mathrm{Cu}$ for ovines is $15 \mathrm{mg} / \mathrm{kg}$ of DM when normal concentration of Mo and S are offered. Copper is one of the main minerals associated with intoxication of ruminants, especially in sheep, but levels found in solid residues were low and represent low intoxication potential to ruminants.

The sources normally used to supply $\mathrm{Mn}$ in the mineral mix are manganese sulfate and magnesium carbonate, with $30 \%$ and $46 \%$ of $\mathrm{Mn}$, respectively. Manganese is an essential element to the animal's metabolism (Pitropvska et al., 2014), in the formation of the organic bone matrix (Zhang et al., 2014) and as a component of several enzymes that are involved in many processes of the organism (Khan et al., 2015). According to NRC (2007) the Mn is not toxic to ruminants even at high levels, but an excess can affect the absorption of Fe. In the NRC (2005), the maximum tolerable level of $\mathrm{Mn}$ is $2.000 \mathrm{mg} / \mathrm{kg}$ of DM.

The $\mathrm{Zn}$ sulfate contains $36 \%$ and oxide contains $72 \%$ of this mineral. Both for $\mathrm{Mn}$ and $\mathrm{Zn}$, the levels observed in the residues are below the ones which traditional sources are able to supply. The APSR showed on average 192.0 $\mathrm{mg} / \mathrm{kg}$ of Mn with one of the samples containing $972 \mathrm{mg} / \mathrm{kg}$, the most expressive of all the examined residues. Zinc is part of the composition of many enzymes of several metabolic pathways and its deficiency can cause reproductive and skeletal disorders, skin and wool anomalies and anorexia (NRC, 2007). Ruminants can tolerate a larger intake of $\mathrm{Zn}$ than non-ruminants. For lambs the maximum tolerable level is $300 \mathrm{mg} / \mathrm{kg}$ of MS (NRC, 2005). 
Table 2. Concentration of microminerals $(\mathrm{mg} / \mathrm{kg})$ in residues samples obtained from saline water (SWSR), aquaculture ponds (APSR) and desalination waste (DWSR)

\begin{tabular}{|c|c|c|c|c|c|c|c|c|}
\hline Sample & $\mathrm{Cu}$ & $\mathrm{Fe}$ & $\mathrm{Mn}$ & $\mathrm{Zn}$ & $\mathrm{Ni}$ & $\mathrm{Cd}$ & $\mathrm{Pb}$ & $\mathrm{Cr}$ \\
\hline \multicolumn{9}{|l|}{ SWSR } \\
\hline 1 & 0.20 & 2.00 & 0.40 & 0.42 & 1.70 & 0.14 & 5.50 & 0.91 \\
\hline 2 & 0.43 & 17.50 & 0.40 & 0.50 & 0.40 & 0.26 & 5.00 & 1.25 \\
\hline 3 & 0.26 & 10.00 & 0.19 & 0.70 & 1.50 & 0.17 & 2.51 & 1.25 \\
\hline 4 & 0.23 & 3.85 & 0.50 & 0.35 & 0.00 & 0.00 & 0.35 & 0.81 \\
\hline 5 & 0.26 & 2.40 & 0.50 & 1.00 & 0.00 & 0.06 & 0.00 & 0.65 \\
\hline 6 & 0.28 & 17.00 & 0.35 & 8.50 & 0.00 & 2.00 & 0.00 & 0.35 \\
\hline 7 & 0.45 & 2.00 & 0.50 & 0.50 & 1.00 & 0.07 & 6.00 & 0.55 \\
\hline 8 & 0.44 & 9.45 & 0.67 & 0.30 & 1.21 & 0.14 & 0.56 & 0.05 \\
\hline 9 & 0.45 & 3.80 & 1.37 & 0.53 & 0.66 & 0.50 & 0.84 & 0.30 \\
\hline 10 & 0.55 & 9.30 & 0.88 & 0.49 & 0.00 & 0.00 & 0.00 & 0.00 \\
\hline 11 & 0.47 & 8.48 & 15.75 & 2.25 & 0.00 & 0.00 & 1.80 & 1.05 \\
\hline 12 & 0.20 & 4.50 & 0.50 & 0.45 & 0.15 & 0.02 & 1.51 & 0.73 \\
\hline Mean & 0.35 & 7.52 & 1.83 & 1.33 & 0.55 & 0.28 & 2.00 & 0.66 \\
\hline SD & 0.12 & 5.22 & 4.21 & 2.22 & 0.62 & 0.54 & 2.16 & 0.41 \\
\hline \multicolumn{9}{|l|}{$A P S R$} \\
\hline 1 & 29.0 & 231.5 & 80.7 & 300.0 & 47.3 & 5.8 & 57.3 & 20.2 \\
\hline 2 & 31.0 & 397.5 & 88.6 & 245.0 & 54.6 & 3.0 & 82.3 & 66.9 \\
\hline 3 & 16.5 & 274.0 & 302.0 & 145.0 & 40.7 & 3.4 & 25.7 & 0.0 \\
\hline 4 & 21.5 & $3,120.0$ & 82.0 & 215.0 & 47.7 & 5.8 & 74.0 & 73.5 \\
\hline 5 & 8.0 & $1,385.0$ & 49.2 & 195.0 & 46.0 & 5.7 & 22.4 & 10.7 \\
\hline 6 & 14.0 & $1,280.0$ & 111.0 & 150.0 & 39.7 & 6.8 & 32.3 & 7.5 \\
\hline 7 & 16.0 & $1,170.0$ & 95.1 & 215.0 & 38.5 & 9.7 & 22.9 & 5.4 \\
\hline 8 & 10.5 & 740.0 & 99.4 & 125.0 & 45.5 & 9.8 & 22.9 & 19.5 \\
\hline 9 & 15.0 & $2,215.0$ & 972.0 & 345.0 & 38.3 & 0.0 & 41.0 & 30.0 \\
\hline 10 & 8.0 & $1,600.0$ & 49.4 & 320.0 & 41.0 & 5.0 & 28.1 & 10.6 \\
\hline Mean & 16.9 & $1,241.3$ & 192.9 & 225.5 & 43.9 & 5.5 & 40.9 & 24.4 \\
\hline SD & 8.0 & 916 & 283.0 & 76.4 & 5.2 & 3.0 & 22.4 & 25.6 \\
\hline \multicolumn{9}{|l|}{$D W S R$} \\
\hline 1 & 0.37 & 6.48 & 32.38 & 161.88 & 0.32 & 0.24 & 0.00 & 0.00 \\
\hline 2 & 0.18 & 5.50 & 27.50 & 137.50 & 0.13 & 0.03 & 0.30 & 0.51 \\
\hline 3 & 0.27 & 2.85 & 14.25 & 71.25 & 0.33 & 0.23 & 0.00 & 0.00 \\
\hline 4 & 0.72 & 13.00 & 65.00 & 325.00 & 1.50 & 0.08 & 0.91 & 0.41 \\
\hline Mean & 0.39 & 6.96 & 34.78 & 173.91 & 0.57 & 0.15 & 0.30 & 0.23 \\
\hline SD & 0.24 & 4.31 & 21.55 & 107.76 & 0.63 & 0.11 & 0.43 & 0.27 \\
\hline
\end{tabular}

Note: $\mathrm{Cu}=$ copper, $\mathrm{Fe}=$ iron, $\mathrm{Mn}=$ manganese, $\mathrm{Zn}=$ zinc, $\mathrm{Ni}=$ nickel, $\mathrm{Pb}=\mathrm{Lead}, \mathrm{Cd}=\mathrm{Cadmium}, \mathrm{Cr}=$ chromium, $\mathrm{SD}=$ standard deviation.

Manera (2013) reported an average inclusion of $1.688 \mathrm{mg} / \mathrm{kg}$ of Fe in the mineral supplements for lambs, ranging from 400 to $2.200 \mathrm{mg} / \mathrm{kg}$. In the SWSR and DWSR, Fe levels were low, presenting 7.52 and $6.96 \mathrm{mg} / \mathrm{kg}$, respectively. However, in the APSR the average was $1.243 \mathrm{mg} / \mathrm{kg}$ with a sample attaining $3.120 \mathrm{mg} / \mathrm{kg}$, representing the baseline or above the levels reported by Manera (2013). Iron sources for ruminant mineral mix such as ferrous sulfate heptahydrate and ferrous carbonate showed $200 \mathrm{~g} / \mathrm{kg}$ and $380 \mathrm{~g} / \mathrm{kg}$, respectively.

Tokarnia et al. (2000) and Peixoto et al. (2005) reported that there is an excess of Fe in mineral supplements for grazing ruminants in Brazil and several regions of the world. Forage and soil intake already supplies the amount of Fe to the animal. In this case, the presence of Fe in the mineral mix can be an anti-economic factor, raising the production cost. According to NRC (2007) an excess of free Fe can cause oxidative membrane damage and high 
level of this element can promote $\mathrm{Cu}$ deficiency in goats and sheep. The NRC (2005) suggests $500 \mathrm{mg} / \mathrm{kg}$ of DM as the maximum limit.

Nickel is required in small amount by the animal and the NRC (2005) describes that $100 \mathrm{mg} / \mathrm{kg}$ is the maximum tolerable level for bovines. Nickel levels observed in SWSR and DWSR were below the maximum levels described for bovines. In the APSR, the average concentration of $\mathrm{Ni}$ was $43.9 \mathrm{mg} / \mathrm{kg}$ with one sample containing $54.6 \mathrm{mg} / \mathrm{kg}$. When reviewing the mineral elements and the nutrient levels of the mineral mix for lambs in Brazil, Manera (2013) related that $\mathrm{Ni}$ was included in only one mineral supplement with a concentration of $20 \mathrm{mg} / \mathrm{kg}$.

Chrome was obtained in small concentrations in the three solid residues. The highest average was observed in the APSR. The trivalent form of this element is not considered toxic, while the hexavalent form is associated with membrane damage. Chrome and nickel are elements required by animals, in which chrome is associated with stress responses, glucose metabolism and immune response, while nickel is required for the ruminant microorganisms (NRC, 2007). In the NRC (1980), it is recommended the value of $1.0 \mathrm{mg} / \mathrm{kg}$ as the maximum limit for $\mathrm{Cr}$. Considering this concentration, three SWSR and nine APSR would be restrictive to their use. Gomes et al. (2013) found elevated levels of $\mathrm{Cr}$, above $1.0 \mathrm{mg} / \mathrm{kg}$ in mineral supplements for dairy cattle and justified these concentrations by the inclusion of natural rocks in the mineral mix.

Cadmium and $\mathrm{Pb}$ were identified in most samples of the examined residues. The mean concentrations of $\mathrm{Cd}$ were $0.28 ; 5.50$ and $0.15 \mathrm{mg} / \mathrm{kg}$ in the SWSR, APSR and DWSR, respectively. However, for Pb, the averages were 2.0, 40.9 and $0.30 \mathrm{mg} / \mathrm{kg}$, respectively. The highest levels of $\mathrm{Pb}$ and $\mathrm{Cd}$ were $82.30 \mathrm{mg}$ and 9.80 in the APSR, respectively. However, these results suggest possible contamination in aquaculture ponds because the water and the desalination waste presented low concentrations of $\mathrm{Ca}$ and $\mathrm{Pb}$.

Cadmium and $\mathrm{Pb}$ are considered toxic to animals. Cadmium is associated with renal damage (NRC, 2001) and $\mathrm{Pb}$ can cause hematologic, reproductive, immune, vascular and renal damage (Pareja-Carrera et al., 2014). They are also antagonistic to other minerals. Cadmium interferes in the absorption and metabolism of $\mathrm{Zn}$ and $\mathrm{Cu}$, as $\mathrm{Pb}$ affects the absorption and function of $\mathrm{Zn}$ (NRC, 2001) and metabolism of $\mathrm{Ca}$ (Pareja-Carrera et al., 2014). In addition, $\mathrm{Ca}, \mathrm{P}, \mathrm{Fe}$ and $\mathrm{Zn}$ can reduce the absorption of $\mathrm{Pb}$ by the animal (NRC, 2001).

The AAFCOI (2001) recommends $0.5 \mathrm{mg} / \mathrm{kg}$ and $30 \mathrm{mg} / \mathrm{kg}$ for $\mathrm{Cd}$ and $\mathrm{Pb}$ as maximum content, respectively. Then, one SWSR and nine APSR showed Cd levels above the recommendation. In the case of Pb, all SWSR and DWSR showed concentrations below $30 \mathrm{mg} / \mathrm{kg}$, while for APSR in five of the ten the concentrations were above this limit.

Maletto (1986) suggested the amount of $10 \mathrm{mg} / \mathrm{kg}$ as the maximum level for $\mathrm{Pb}$, which would restrict all APSR samples, where the lowest value found was $22.4 \mathrm{mg} / \mathrm{kg}$. On the other hand, the SWSR and DWSR remained below the maximum level, although, in three SWSR samples and in two DWSR the presence of $\mathrm{Pb}$ was not observed.

Marçal et al. (2005) also observed Pb levels above $30 \mathrm{mg} / \mathrm{kg}$ in commercial mineral mix for bovines in Brazil. Similarly, Marçal et al. (2003) examined the levels of $\mathrm{Cd}, \mathrm{Pb}$ and other heavy metals in phosphate sources to be used in mineral supplements and they observed contamination by xenobiotics, except for bicalcium phosphate. In the case of $\mathrm{Cd}$, some samples (phosphate rocks) showed levels exceeding $0.5 \mathrm{mg} / \mathrm{kg}$, the limit suggested by AAFCOI (2001), while for $\mathrm{Pb}$ the levels observed were below the recommended.

The SWSR and DWSR showed potential as source of $\mathrm{NaCl}$ and contributed to other mineral to a lesser degree. The macrominerals showed concentrations that were not potentially toxic to the animals and should be considered in the mineral nutrition in order to avoid imbalances and antagonism. Iron was found in high concentrations in a part of the samples, which can affect other mineral elements, while $\mathrm{Mn}, \mathrm{Zn}, \mathrm{Cu}$ and Ni showed low levels. The concentrations of $\mathrm{Cr}, \mathrm{Pb}$ and $\mathrm{Cd}$ were found to be the most restrictive factors for the use of the residues for mineral mix, presenting concentrations that exceeded the safe levels.

Manera et al. (2014) included 20\% of APSR in mineral mix for lambs and observed that mineral and feed intakes, as well as water intake, were similar for animals receiving commercial supplement compared to those consuming the mineral supplement made from APSR. The hydric balance and the dry matter digestibility were not affected by mineral supplements (Manera et al., 2014), which is an indicative of the possibility to include this solid residue in mineral mix for lambs. However, additional research is needed to better understand the response of the animals to these sources, apart from the examination of the economic viability of the process.

\section{Conclusions}

The examined saline residues from aquaculture ponds (APSR), saline water (SWSR) and desalination waste (DWSR) presented large variation in mineral elements. The SWSR and DWSR presented potential as sources of $\mathrm{Na}$ and $\mathrm{Cl}$, while the APSR can contribute with $\mathrm{Ca}$. All examined saline sources were poor in $\mathrm{P}$ and $\mathrm{Ca}$ and trace 
minerals except for the APSR, which displayed a reasonable concentration of Ca. Some samples of SWSR and APSR presented heavy mineral levels that can be potentially toxic to ruminants.

\section{References}

Amorim, M. C. C., Porto, E. R., \& Silva Júnior, L. G. (2000). Evaporação solar como alternativa de reuso dos efluentes da dessalinização por osmose inversa. Anais do Congreso Interamericano de Ingeniería Sanitaria y Ambiental (Vol. 27, pp. 3-8). Porto Alegre, RS, Brasil.

Amorim, M. C. C., Porto, E. R., \& Silva Júnior, L. G. A. (2004b). Evaporação solar como alternativa de reuso dos efluentes da dessalinização por osmose inversa. Retrieve from http://www.cepis.org.pe/bvsaidis/aresid ua/i-007.pdf

Amorim, M. C. C., Porto, E. R., Matos, A. N. B., \& Silva, D. F. (2004a). Diagnósticos de sistemas de dessalinização de água salobras subterrâneas em municípios do estado da Paraíba, Brasil. Anais do Congresso Brasileiro de Águas Subterrâneas (Vol. 13). São Paulo, SP, Brasil.

Association of American Feed Control Officials Incorporated (AAFCOI). (2001). Official guidelines for contaminant levels permitted in mineral feed ingredients. Indiana: AAFCOI.

Castillo, A. R., St-Pierre, N. R., Silva del Rio, N., \& Weiss, W. P. (2013). Mineral concentrations in diets, water, and milk and their value in estimating on-farm excretion of manure minerals in lactating dairy cows. Journal of Dairy Science, 96, 3388-3398. http://dx.doi.org/10.3168/jds.2012-6121

Gomes, A. C. S., Lindino, C. A., Gonçalves Junior, A. C., \& Gomes, G. D. (2013). Determinação de Cd, Cr e Pb no leite e na alimentação bovina do Brasil. Revista do Instituto Adolfo Lutz, 72, 211-218. http://dx.doi.org/ 10.18241/0073-98552013721566

Herdt, H. H., \& Hoff, B. (2011). The use of blood analysis to evaluate trace mineral status in ruminant livestock.Veterinary. Clinics of North America: Food animal Practice, 27, 255-283. http://dx.doi.org/ 10.1016/j.cvfa.2011.02.004

Karn, J. F. (2001). Phosphorus nutrition of grazing cattle: A review. Animal Feed Science and Technology, 89, 133-15. http://dx.doi.org/10.1016/S0377-8401(00)00231-5

Khan, Z. I., Ahmad, K., Ashraf, M., Naqvi, S. A. H., Seidavi, A., Akram, N. A., \& Tufarelli, V. (2015). Evaluating pasture and soil allowance of manganese for Kajli rams grazing in semi-arid environment. Tropical Animal Health and Production, 47, 563-566. http://dx.doi.org/10.1007/s11250-015-0763

Kim, D. H. (2011). A review of desalting process techniques and economic analysis of the recovery of salts from retentates. Desalination, 270, 1-8. http://dx.doi.org/10.1016/j.desal.2010.12.041

Malafaia, P., Costa, R. M., Brito, M. F., Peixoto, P. V., Barbosa, J. D., Tokarnia, C. H., \& Döbereiner, J. (2014). Equívocos arraigados no meio pecuário sobre deficiências e suplementação mineral em bovinos no Brasil. Pesquisa Veterinária Brasileira, 34, 244-249. http://dx.doi.org/10.1590/S0100-736X2014000300008

Maletto, S. (1986). Correlação da nutrição mineral e a sanidade. Anais do Seminário sobre nutrição mineral (p. 38). São Paulo, SP, Brasil.

Manera, D. B. (2013). Misturas minerais oriundas de resíduos salinos sólidos para cordeiros (Dissertação de mestrado). Universidade Federal do Vale do São Francisco, Petrolina, Pernambuco.

Manera, D. B., Voltolini, T. V., Menezes, D. R., \& Araújo, G. G. L. (2014). Mineral mixtures from solids salt residues for lambs. Revista Brasileira de Zootecnia, 43, 485-49. http://dx.doi.org/10.1590/S1516-359820 14000900005

Marçal, W. S., Gastel, L., Nascimento, M. R. L., \& Oliveira, H. S. (2003). Teores de chumbo em suplementos minerais comercializados no estado de Mato grosso e Mato Grosso do Sul. Ciência Rural, 33, 775-778. http://dx.doi.org/10.1590/S0103-84782003000400032

Mcdowell, L. R. (1989). Vitamins in animal nutrition: Comparative aspects to human nutrition (p. 486). San Diego: Academic Press.

Mendonça Junior, A. F. (2011). Minerais importância de uso na dieta de ruminantes. Agropecuária Científica no Semi-Árido, 7(1), 1-13.

Ministério da Agricultura Pecuária e Abastecimento (MAPA). (2004). Instrução Normativa $n^{\circ} 12$ de 30 de Novembro de 2004. Governo Federal: Brasília. Retrieved August 10, 2015, from http://www.mapa.gov.br 
Mohammed, A., Campbell, M., \& Youssef, F. G. (2014). Serum copper and haematological values of sheep of different physiological stages in the dry and wet seasons of Central Trinidad. Veterinary Medicine International, Article ID 972074. http://dx.doi.org/10.1155/2014/972074

National Research Council. (1980). Mineral tolerance of domestic animals. Washington, D.C.: National Academic Press.

National Research Council. (2nd ed.). (2005). Mineral tolerance of animals. Washington, D.C.: National Academic Press.

National Research Council. (7th ed.). (2001). Nutrient requeriments of dairy cattle. Washington, D.C.: National Academic Press.

National Research Council. (7th ed.). (2007). Nutrient requeriments of small ruminants. Washington, D.C.: National Academic Press.

Nogueira, A. R. A., \& Souza, G. B. (2005). Tecido vegetal. Manual de laboratórios: Solo, água, nutrição vegetal, nutrição animal e alimentos (p. 334). São Carlos: Embrapa Pecuária Sudeste.

Pareja-Carrera, J., Mateo, R., \& Rodríguez-Estival, J. (2014). Lead (Pb) in sheep exposed to mining pollution: Implications for animal and human helath. Ecotoxicologyand Environmental Safety, 108, 210-216. http://dx.doi.org/10.1016/j.ecoenv.2014.07.014

Peixoto, P. V., Malafaia, P., Barbosa, J. D., \& Tokarnia, C. B. (2005). Princípios de suplementação mineral em ruminantes. Pesquisa Veterinária Brasileira, 25(3), 195-200. http://dx.doi.org/10.1590/S0100-736X200500 0300011

Pitropovska, E., Pechová, A., Hauptmanová, K., Husáková, T., \& Pavlata, L. (2014). The effect of manganese supplementation on its concentrations in blood, hair, and organs of goat kids. Acta Veterinaria Brno, 83, 219-224. http://dx.doi.org/10.2754/avb201483030219

Porto, E. R., Amorim, M. C. C. de, \& Silva Júnior, L. G. A. (2001). Uso do rejeito da dessalinização de água salobra para irrigação da erva-sal (Atriplex nummularia). Revista Brasileira de Engenharia Agrícola e Ambienta, 15(1), 111-114. http://dx.doi.org/10.1590/S1415-43662001000100020

Prasad, C. S., Mandal, A. B., Gowda, N. K. S., Sharma, K., Pattanaik, A. K., Tyagi, P. K., \& Elangovan, A. V. (2015). Enhancing phosphorus utilization for better animal production and environment sustainability. Current Science, 108, 1315-1319.

Puls, R. (1994). Mineral levels in animal health diagnostic data (2nd ed.). Clearbrook, Canada: Sherpa International.

Shahmansouri, A., Min, J., Jin, L., \& Bellona, C. (2015). Feasibility of extracting valuable minerals from desalination concentrate: A comprehensive literature review. Journal of Cleaner Production, 100, 4-16. http://dx.doi.org/10.1016/j.jclepro.2015.03.031

Soares, T. M., Silva, I. J. O. da, Duarte, S. N., \& Silva, E. F de F. (2006). Destinação de águas residuárias provenientes do processo de dessalinização por osmose reversa. Revista Brasileira de Engenharia Agrícola e Ambiental, 10, 730-737. http://dx.doi.org/serials/j_1294909788578

Tokarnia, C. H., Dobereiner, J., \& Peixoto, P. V. (2000). Deficiências minerais em animais de fazenda, principalmente bovinos. Pesquisa Veterinária Brasileira, 20(3), 127-138. http://dx.doi.org/10.1590/S0100736 X2000000300007

Tokarnia, C. H., Dobereiner, J., Moraes, S. S., \& Peixoto, P. V. (1999). Deficiências e desequilíbrios minerais em bovinos e ovinos: Revisão de estudos realizados no Brasil de 1987 a 1998. Pesquisa Veterinária Brasileira, 19, 47-62. http://dx.doi.org/10.1590/S0100-736X1999000200001

Wilkens, M. R., Oberheide, I., Schröder, B., Azem, E., Steinberg, W., \& Breves, G. (2012). Influence of the combination on of 25-hydroxyvitamin $\mathrm{D}_{3}$ and a diet negative in cation-anion difference on peripartal calcium homeostasis of dairy cows. Journal of Dairy Science, 95, 151-164. http://dx.doi.org/10.3168/ jds.2011-4342

Xu, P., Cath, T. Y., Robertson, A. P., Reinhard, M., Leckie, J. O., \& Drewes, J. E. (2013). Critical review of desalination concentrate management, treatment and beneficial use. Environmental Engineering Science, 30 , 502-514. http://dx.doi.org/10.1089/ees.2012.0348 
Zhang, H. H., Zhou, N., Zhang, T. T., Bao, K., Xu, C., Song, X. C., \& Li, G. Y. (2014). Effect of different manganese levels on growth performance and $\mathrm{N}$ balance of growing Mink (Neovision vision). Biological Trace Element Research, 160, 206-211. http://dx.doi.org/10.1007/s12011-014-0008-6

\section{Copyrights}

Copyright for this article is retained by the author(s), with first publication rights granted to the journal.

This is an open-access article distributed under the terms and conditions of the Creative Commons Attribution license (http://creativecommons.org/licenses/by/4.0/). 